\title{
THE SEMANTIC ANALYSIS OF THE CONCEPTUAL FIELDS "WEALTH" IN THE ENGLISH LANGUAGE
}

\author{
Inna COLENCIUC \\ Free International University of Moldova
}

The article is devoted to the peculiarities of functioning of the conceptual fields "wealth" with monolexical and polilexical units in the English language. The author begins her theoretical research by presenting the approaches to defining the term"concept" by different scholars. It is regarded as either a linguistic-cognitive or a cultural-linguistic phenomenon. Then we analyse the theory of "the concept" suggested by Yuri Stepanov, confronting it with the opinions of others and expressing our personal point of view. The concept, unlike the word, has a more complicated structure. Its content is divided into linguistic meaning and cultural sense. The study of the vocabulary from the point of view of systematization and structuring into subsystems of different areas has recently become of paramount importance. The conceptual field is defined as a complex structure, which provides interconnected components verbalizing various aspects of the field. The field is not viewed just as a collection of concepts whose features are ordered in a certain hierarchy but as a system of overlapping cognitive structure. For this contribution, we consulted the works of different linguists who carried out research on the theme such as Western scholars: J. Trier, G. Ipsen, V. Porzig, J.Lyons, V. Evans, E. Coserio, Russian scholars: D. Lihacev, and Yu. Stepanov as well as Moldovan researchers S. Berejan, A. Ciobanu and V.Bahnaru. Monolexical units have been selected for the semic analysis of the constuents of the fields. Numerous examples of polilexical units are offered and their classification is presented.

Key words: Concept, conceptual field, monolexical unit, polilexical unit, seme, semic analysis

At present stage of linguistic research, several approaches to the understanding of the term "concept" are identified. Scholars from different countries treat the concept as a linguistic- cognitive or cultural-linguistic phenomenon. Each approach, made on the basis of certain characteristics, highlights the specific aspect of the concept.

One approach regards the concept as a cultural phenomenon. Yuri Stepanov defines the term as "a basic cultural cell in the mental world of a man" (Степанов 248). According to him, the concept is a mental structure that represents the knowledge of an individual about a particular segment of the world. As a part of the world picture, the concept reflects the orientation of values of both the individuals and the entire linguistic community. It means that the concept may comprise the generally valid features as well as the individual characteristics of native speakers.

The supporters of another approach suggest viewing the concept as a linguistic-cognitive phenomenon. The concept provides the information about what an individual knows, suggests, thinks, and imagines about the objects of our world. According to this view, the concept is connected to the verbal means of expression. "It is a kind of algebraic expression of meaning, which a man creates in his written speech" (Лихачев 28). The researchers of this approach argue that a language does not form concepts but serves as a means of exchanging and discussing in the process of speaking. In communication, the concept can be verbalized by 98 
individual words and phrases and by sentences and the entire texts, which determines the concept itself. The choice of the verbal form depends on the personal meaning, mental representation, and the speaker's vocabulary, which are interconnected.

The term "concept" can be defined as a unit of knowledge, an abstract idea or a mental symbol. In contrast to the "word", it has a more complicated structure. The content of the concept is divided into linguistic meaning and cultural sense.

V. Evans believes that concepts are organized by the field principle (Evans 43). This principle of the system organization of linguistic facts is regarded as one of the most remarkable achievement of modern linguistics. The term "field" traces back to the definition of the language as the system, representing the complex mechanism, which was theoretically explained by F. de Saussure. Scholars of different countries and of national school of linguistics, including S. Berejan, A. Ciobanu and V.Bahnaru define the "field" differently. This suggests different approaches to the problem development, rather than the differences of fundamental theoretical character.

The notion of "field" was borrowed from physics and through psychology and biology was introduced into linguistics, in particular by J. Trier. Among those adopting the term, we can name G. Ipsen and V. Porzig. V. Porzig represented the linguistic field in a new form in which words belong together not only as to meaning but are assimilated according to various formal and functional aspects (Porzig 71).

As far as the conceptual field is concerned, it is defined as a concrete linguistic bilateral unity; its plan of content includes certain semantic elements. We formulated this definition, following the idea of J. Lions who regarded it as "specifically organized totality of language units and speech phenomena of different levels" (Lions 108). These units are united by some common elementary meaning, which forms the basis of the semantic category. Notable linguist E. Coseriu and his disciple state that lexical fields differ from conceptual fields. Every lexeme implies one concept, but not every concept is necessarily rendered by one single lexeme. Concepts may also be expressed by the means of phrases and clauses (Coseriu, Geckeler 95).

The actuality of the theme is conditioned by the process of global integration in the modern world and a growing interest in the problems of ethnocultural character. Wealth represents an extremely sensitive realm of human activity. It is an emotionally coloured theme, which is widely discussed on an interpersonal level, in the mass media, on the Internet and in fiction. Literary works abound in so-called rags-to-riches stories. The corpus of vocabulary related to wealth differs in richness from nation to nation, being influenced by historical development, social beliefs, and dominant ideology.

Let us analyze the conceptual field "wealth" with monolexical units in the English language: abundance, affluence, bale, bankroll, Benjamins, bezant, bomb, bonanza, bundle, capital, cartwheel, china, chip, chunk, dough, eagle, estate, finance, florin, funds, gold, grand, green, kitty, loot, luxury, Mammon, megabucks, mint, money-bag, monkey, noble, nuggets, offloof, packet, pecunia, pelf, pile, pocket, pot, property, resources, riches, roll, rosenoble, sceat, silver, sovereign, treasure, thremissas, wealth, welfare. 
Semic analysis was developed within the field of interpretive semantics (the study of meaning in linguistic units). The signified of any semantic unit can be broken down into semes, or features of content.

The field "wealth" (abundance of valuable possession or money) under analysis includes the following constituents or semes (Бережан 101): S1 - wealth; S2 - coins; S3 - banknotes; S4 - official style; S5 - colloquial/ slang; S6 - transfer of meaning; S7 - archaism; S8 - neologism; S9 - pejorative/negative; S10 positive; S11 - neutral; S12 - religious/mythological allusion; S13 - image; S14 colour; S15 - food; S16 - proper name; S17 - games of chance; S18 - precious metal S18/1 - gold; S18/2- silver; S19 - currency; S20 - quantity; S21 - property; S22 - illegal

The seme characteristics: abundance S1S4S10; affluence S1S4S11; bale S1S3S5S11S20; bankroll S1S3S4S11S20; Benjamins S1S3S5S6S10S16; bezant S1S2S7S10S18/1S19; bomb S1S5S6S8S9S20; bonanza S1S5S9S18/1S20; bundle S1S3S5S11S20; capital S1S4S11; cartwheel S1S2S5S7S9S18/2; china S1S5S6S8S11S20; chip S1S5S9S17; chunk S1S5S10S20; dough S1S5S6S10S15S20; eagle S1S2S5S7S10S18/1; estate S1S4S11S21; finance S1S4S11; florin S1S2S7S10S13S18/1S19; funds S1S4S11S20; gold S1S4SS1018/1; grand S1S3S5S10S20; green S1S3S5S10; kitty S1S5S10S17; loot S1S5S9S22; luxury S1S3S10S18S21; Mammon S1S5S9S12S18; megabucks S1S3S5S10S20; mint S1S5S10S20; money-bag S1S511S20; monkey S1S3S5S6S10S2; noble S1S2S7S10S18/1S19; nuggets S1S5S10S18/1; offloof S1S5S9; packet S1S3S5S11S20; pecunia S1S5S11S20; pile S1S3S5S11S20; pocket S1S5S11S20; pot S1S5S6S10S20; property S1S4S11S21; resources S1S4S11; riches S1S4S11; roll S1S3S4S11S20; rosenoble S1S2S7S10S13S18/1S19; sceat S1S2S7S10S18/S19; silver S1S4SS1018/2; sovereign S1S2S7S10S18/21S19; treasure S1S4S10S18; thremissas S1S2S7S10S18/1S19; wealth S1S4S11; welfare S1S4S1121

As it can be seen from the list given above, the seme $\mathrm{S} 1$ that defines the word "wealth" is common for all the elements of the considered field. That is to say, its meaning is an obligatory component for other elements of the field (it is termed archilexeme). It can be used while explaining the meaning of other words. Among the elements of the conceptual field, there are parasememes: bonanza S1S5S9S18/1S20 and loot S1S5S9S22, pocket S1S5S11S20 and pot S1S5S6S10S20

There are elements of the field with the same constituents; such as bale, bundle, packet, pile -S1S3S5S11S20 they have common semantic characteristics and imply a big amount of banknotes. Among synonyms, we can name affluence and riches; finance-fund; pocket and money-bag. Functional differences between sememes with common constituents can be revealed at the stylistic level (affluence and wealth belong to the official style, off/oof - to colloquial.

There are lexical units related to "wealth" characterized by the transfer of meaning. For example, Benjamins implies the banknotes of 100-dollar denomination; dough means a big sum of money, monkey is 500 pounds. These units as well as cartwheel, china, eagle, green, kitty are characterized by a metaphorical nomination of wealth.

According to Oxford American dictionary, the majority of lexical units have either positive or neutral connotation. The words bomb, bonanza, loot, Mammon, offloof, and pelf imply negative shades of meaning. 
The conceptual field "wealth" with polilexical units includes the idiomatic expressions: bags of money, big bucks, nice piece of jack, heavy / big / important / real money, oodles of money, pots of money, even money, lump sum, dirty / filthy / nigger rich. A still more emotional and obviously negative assessment of somebody's riches is represented in a series of two-word idioms of the Adj. + Adj. type: dirty / filthy / nigger rich - very rich (Хошовска 38).

A comparison of these clusters of idioms demonstrated above suggests us an idea of their being the result of some reserved or emotionally coloured utterance in a repeated situation of discussing somebody's (and not the speakers') financial matters. Indeed, no other topic generates so much curiosity, jealousy and envy; hence we can speak of the attitudinal character of idiomatic expression colouring. In this respect, again, we could split the bulk of idioms referring to "much money" into relatively neutral, emotional and highly emotional (ranging on derogatory).

Table 1. Assessment of Wealth (Elaborated by the author).

\begin{tabular}{|l|l|}
\hline \multicolumn{1}{|c|}{ RELATIVELY NEUTRAL } & \multicolumn{1}{c|}{ EMOTIONAL } \\
\hline $\begin{array}{l}\text { to be in the money } \\
\text { to be in the bucks } \\
\text { to be in the chips } \\
\text { to be in tall cotton / to be sitting } \\
\text { pretty }\end{array}$ & $\begin{array}{l}\text { to be flush / made of money } \\
\text { to wallow / roll in money } \\
\text { to have money to burn } \\
\text { to rake in the money }\end{array}$ \\
\hline $\begin{array}{l}\text { NEGATIVE EMOTIONAL ASSESSMENT: To stink in / with money } \\
\text { (coll.) }\end{array}$ \\
\hline
\end{tabular}

Owing to the mass media, lively open and widely circulating discussions of personal financial situations cannot but generate utterances that that are only close to literary style, and in no case do they resemble the language of official financial accounts. With time, slangy colloquialisms creep onto newspaper columns, and a foreigner (especially a Moldovan citizen) gets stunned to learn that "turning" money means "earning" it (Dimo 84) . There is a stratum of idiomatic expressions, traditional in many cultures, which reveal pursuit or idolization of wealth: As rich as Croesus, to worship the golden calf, to serve Mammon.

The units above bear a universal allusion-based character and are easy to understand, however, they demand the knowledge of biblical and mythological realities.

We suggest the following classification of polilexical units:

\section{TO HAVE MUCH MONEY}

a) neutral assessment: to be in the money; to be in the bucks; to be in the chips; to be in tall cotton / to be sitting pretty - to be very successful; to enjoy excellent fortune

b) emotionally coloured: to have money to burn - to have more money than one needs; to be flush / made of money; to wallow / roll in money; to stink in / with money - colloquial, derogatory

\section{ASSESSMENT}

a) general enrichment mode specified: to turn / to knock down - to earn; to be in the good / better off - to be in a state of profit; to strike it rich - to become rich; to make a bomb (on smth) - to achieve enormous profits; to make a killing - to 
achieve huge profit; to hit the jackpot - to have a big financial success; to shake the money tree - to make a big profit

b) details of enrichment / emotionally coloured: to coin / mint money - to make a fortune quickly; to clean up - to make a profit on a single transaction; to be quids in - to make a good profit on a deal; to coin / mint money - to make a fortune quickly; to cut / end of N\% - a share in some profit or commission; to line one's pockets - to become rich or make much money (esp. in a dishonest way) to get a windfall - to get a profit that is not expected

The study revealed some specific character and a wide scale of perception of the concept "wealth", which is inherent to the native English speakers. As it can be seen from the field with monolexical units, the concept "wealth" is closely connected to respect for the rich and pursuit to get more money. It also showed that the English language is characterized by the presence of cognitive metaphors and metonymous means of the concept actualization. The conceptualization of the phenomenon of wealth through a metaphor occurs as a result of cognitive processing of knowledge about the reality. The main motives for assigning names to lexical units are the image, color, food product, material or precious metal, and a political leader's name. The analysis presented the peculiarity of English expressions as means of linguistic attitudinal assessment of the phenomenon reflected by the idiom components. As far as the problem of respect for wealth is concerned, it should be noted that people's attitude to financial well-being vary from positive, neutral to pejorative and negative.

\section{Bibliographical References}

Bahnaru, Vasile. Elemente de semasiologie română. Chişinău: Ştiinţa, 2009.

Coşeriu, Eugeniu; Gecker, Horst. Orientări în semantica structurală..Traducere de Munteanu, Cristinel. Iaşi: $\quad$ Editura Universităţii „Alexandru Ioan Cuza”, 2016.

Dimo, Olga. The World of Money in its Idiomatic Reflection // Interconexiunea paradigmelor didactice şi metodologice în predarea limbilor străine: Materialele seminarului metodologic cu participare intern. din 25 ian. 2011. Chisinau.: ULIM, 2011, pp. 83-90.

Evans, Vyvyan. How Words Means. Oxford: Oxford University Press, 2009

Ipsen, Günther. Der neue Sprachbegriff. // Zeitschrift für Deutschkunde. Leipzig Berlin, Bd.46, Hft.1, 1932, p. 34 - 52.

Lyons, John. Structural Semantics. Oxford: Blackwell, 2003.

Porzig, Walter. Wesenhafte Bedeutungsbeziehungen. // Beitrage zur Geschichte der deutschen Sprache und Literatur, Halle (Saale), Bd.58, Hft.1-2, 1934, p.70-81.

Trier, Jost. Der deutsche Wortschatz im Sinnbezirk des Verstandes. Von den Anfangen bis zum Beginn des. Jahrhunderts. Heidelberg: Carl Winter Universitatsverlag, 1973.

Бережан, Сильвиу. Семантическая эквивалентность лексических единии. Кишинев: Штиинца, 1973.

Лихачев, Дмитрий. Конщептосфера русского языка. Москва: Академия, 1997.

Степанов, Юрий. Конщептыл. Тонкая пленка циивилзащии. Москва: Языки славянских культур, 2007

Хошовская, Божена. Идиоматические выражения в деловом английском языке. Санкт-Петербург: Лань, 1997.

Oxford American Dictionary. New York: Avon Books, 2001.

Roget's $21^{\text {st }}$ Century Thesaurus. New York: The Philip Lief Group, Inc., 2000. 